\title{
固形造影剤を用いた曣下動態の検討
}

\author{
稲木 匠子・丘村熙 \\ 森敏裕・福井 康二

\section{Clinical Application of Solid Bolus for Evaluation of Swallowing Function}

\author{
Shoko Inaki, Hiroshi Okamura, Toshihiro Mori and Koji Fukui \\ (Ehime University)
}

The purpose of this paper is to discuss the differences of pharyngeal swallowing according to the type of bolus. Using hand-made solid boluses, the authors examined the swallowing function of 36 individuals, 17 patients with a sensation of lump in the throat (group 1) and 19 patients with difficulty swallowing a solid bolus (group 2) through the fluorography. Two transit times of the movements of the boluses (liquid and solid) were measured ; phase 1 represented the time between the passing of the apex of the bolus from the faucial isthmus to the entrance of the esophageal, and phase 2 the time it took the bolus to pass through the esophageal orifice. For liquid boluses, no significant difference was detected between the 2 groups for either phase 1 or phase 2. On the other hand, the phase 1 transit time for a solid bolus was longer than that for a liquid bolus, especially in group 2 . In addition, the solid bolus was arrested at the level of the vallecula and/or pyriform sinus in 15 patients (42\%). Therefore, the use of the solid bolus made clear the existence of a swallowing disorder in the pharyngeal phase, especially the decrease of swallowing power of the oral and pharyngeal muscle and/or the lowered sensitivity of the swallowing reflex.

Key words: solid bolus, fluorography, swallowing function

\section{はじめに}

與哭下障害例において bolus の種類, 性状によ り䛊嚥の程度に差が生じることがある。また嚥 下障害はないものの曣下困難感を訴える症例で, 液体造影剤での検查では異常を検出できない場 合もしばしば経験する．著者らは與下機能評価 法の一つとして私製の固形造影剤による咽頭食 道透視を行い，與葆下負荷試験法としての有用性 を明らかにしている11. 今回，咽喉頭部に閉塞 感, 異物感を訴える咽喉頭異常感症例と固形物
が通りにくいなど食塊嬿下時に異常を訴兄る症 例に扎いて液体造影剂と固形造影剂による與下 動態の検討を行ったので報告する.

\section{検查方法}

固形物嚥下の観察を目的として固形造影剂 (バリウムパン)を作成した。バリウムパンは市 販の蒸しパンミックス $60 \mathrm{~g}$ にバロスパース ${ }^{\mathbb{2}} 40 \mathrm{~g}$ と水 $75 \mathrm{ml}$ を加光, 約10分間蒸して作った1).

食道透視はまず $140 \%$ 硫酸バリウム $20 \mathrm{ml}$ に より液体の燕下を観察し，誤嚥のないことを確 
かめた後,一口約 $8 \mathrm{~cm}^{3}$ のバリウムパンにより 固形の燕下動態の検討を行った，液体造影剂検 查後には，水で口をゆすぎ口腔内の状態を一定 にするようにした。体位は立位で，透視所見は すべてVTRに録画し，著者らが開発したデジ タル・フルオログラフィー法2)にて定性的执よ び定量的解析を行った.

\section{対象}

検討した症例は36例（男性21例，女性15例)で， 年齢は 19 歳より 83 歳でその平均值は52.6歳 $(\mathrm{SD}=13.9)$ であった。対象症例の内訳は咽喉 頭部に閉塞感, 異物感を訴光る咽㗋頭異常感症 例 17 例 (以下異常感群, 平均年齢 $53.6 \pm 13.4$ 歳), 固形物が通りにくいなど食塊蔡下時に異常を訴 える症例19例 (以下興下困難群, 平均年齢51.6 土14.3歳)であった。なお，すべての症例に拉 いて液体造影剤では誤曣を認めていない。

\section{結果}

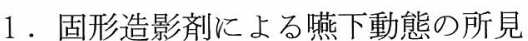
まず咽喉頭部特よび與下動態に異常のない正
常ボランティア 5 名(平均年齢 $35.5 \pm 6.7$ 歳)に 扔いて予備検査を行った。検討した正常例では すべてバリウムパンは口峡部より咽頭へスムー ズに送り込まれ食道入口部を通過した。そ連 続画像を図 1 亿呈示する。

異常感群，與下困難群では正常例とは異なる 以下の種々の所見が認められた。 (1)バリウムパ ンが舌根より咽頭へなかなか送り込まれない （図 2 ）：4 例，(2)バリウムパンが喉頭蓋谷に達 して初めて器下反射が誘発される：5例，(3) シ リウムパンの一部が喉頭蓋谷に残る（図 3 ）：9 例，(4)バリウムパンの一部が下咽頭に残る（図 4)：8例，(5)バリウムパンが咽頭より口腔へ 逆流する：2 例，などで，各群に和ける各所見 の発現頻度を表 1 に示した。 これらの所見を 1 つ以上有する症例は曣下困難群で19例中 10 例 $(52.6 \%)$ と多く，一方，異常感群に扮いても 17 例中 5 例 $(29.4 \%)$ に認められた。

2. bolus の通過時間

bolus の先端がロ峡部を越光食道入口部に達
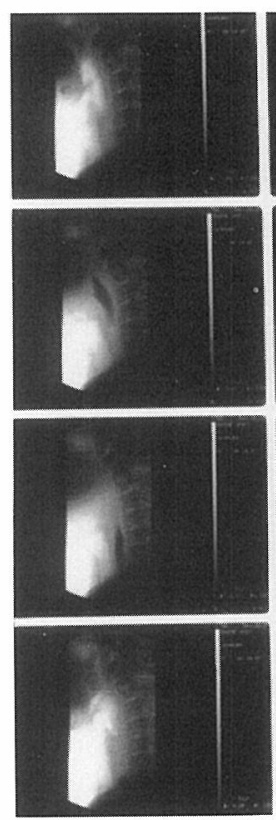
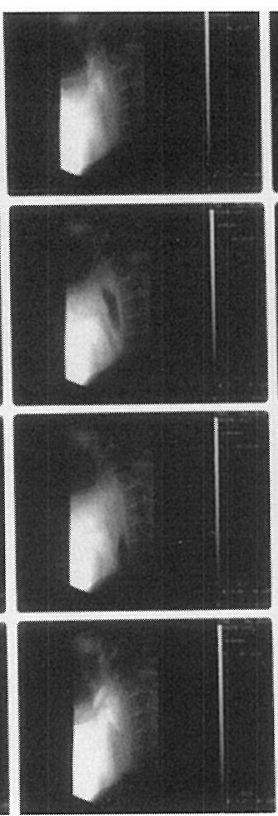
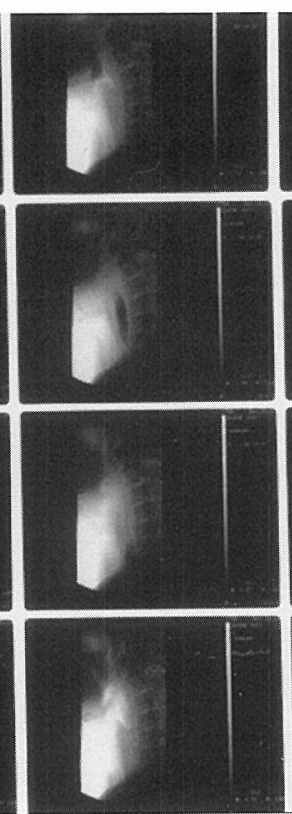
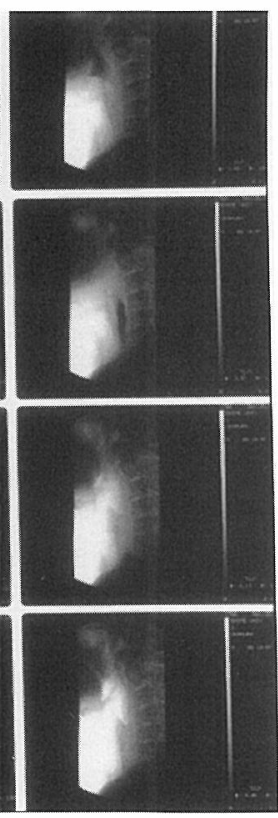

図 1 正常例のバリウムパン曣下動態所見 1 フレーム間隔 $33 \mathrm{msec}$. 


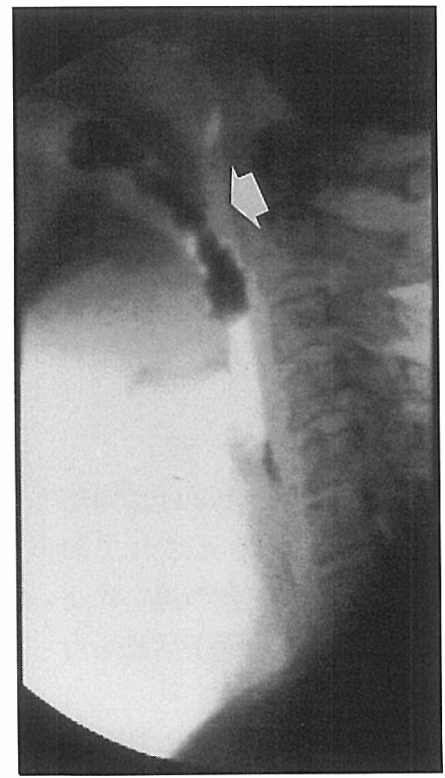

図 2 舌根に貼りついているバリウムパン (矢印)

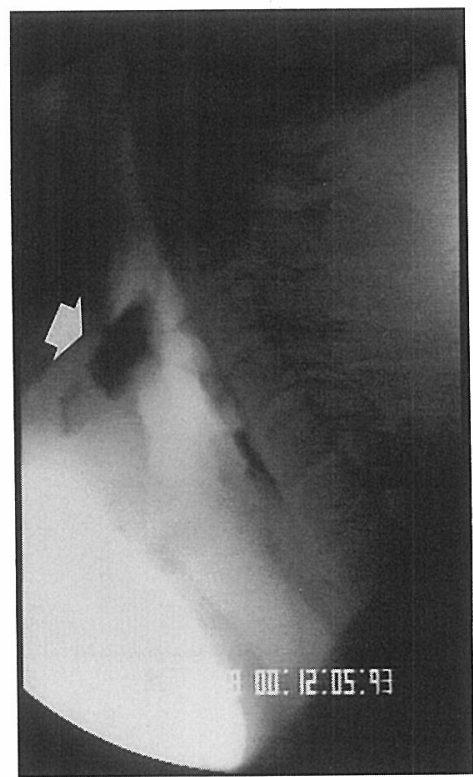

図 3 喉頭蓋谷に残っているバリウムパン (矢印)
するまでの時間 (A值)とbolus が食道入口部を 通過する時間 $(\mathrm{B}$ 值)を液体造影䨩とバリウムパ ンで時間分析を行った。A值は與茄下反射， bolus の推進力を, B 值は輪状咽頭筋の弛緩時 間を反映していると推察している。これらの時 間的因子を 2 群間で検討した．各群の各症例の $\mathrm{A}$ 值捻よび $\mathrm{B}$ 值を図 5 亿, 各群平均值(測定不 能例は除く)を表 2 に示す。

表 1 固形造影㘊透視所見の群別内訳

\begin{tabular}{|c|c|c|}
\hline & 異常感群 & 嚥下困難群 \\
\hline $\begin{array}{l}\text { 舌根より咽頭へ送り込 } \\
\text { みにくい }\end{array}$ & $1(5.9)$ & $3(15.8)$ \\
\hline $\begin{array}{l}\text { 喉頭蓋谷に達して嚥下 } \\
\text { 又射が起こる }\end{array}$ & $1(5.9)$ & $4(21.1)$ \\
\hline 一部が喉頭蓋谷に残る & $3(17.6)$ & $6(31.6)$ \\
\hline 下咽頭で分割される & $3(17.6)$ & $5(26.3)$ \\
\hline 口腔へ逆流する & 0 & $2(10.5)$ \\
\hline 観察症例数 & 17例 & 19例 \\
\hline
\end{tabular}

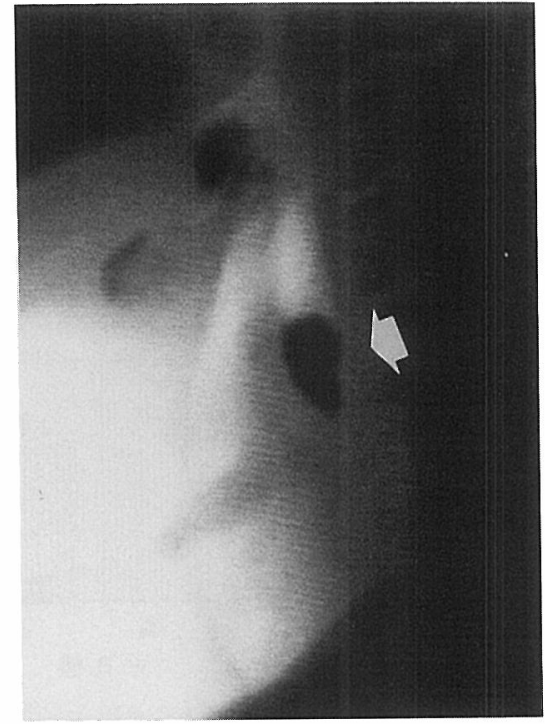

図 4 梨状陥凹に残っているバリウムパン (矢印) 


\section{1) 液体造影剂(図 $5 \mathrm{a}$ )}

検討した症例の液体造影剤(140\%硫酸バリウ ム $20 \mathrm{ml}$ )の通過時間では A值, B 值ともに異 常感群，與燕下困難群間に差異はなかった。

2 ) 固形造影剤(図 $5 \mathrm{~b}$ )

バリウムパンの通過時間 B值は嚥下困難群の 測定困難であった 1 例を除いては液体造影剤と 同様に 2 群間で差異はなく，また液体造影剤の B值とも汪とんど差は認められなかった。なお， 測定困難の 1 例は後述する $\mathrm{A}$ 値の測定も困難で, 咀嚼されたバリウムパンが少量ずつ咽頭に入り 食道入口部を通過するため測定困難とした。

$\mathrm{A}$ 值は両群ともに液体造影剤に比較して個々 の差が大きく測定困難例も 4 例と B 值に比べ多

表 2 造影剤通過時間の平均值と範囲 (msec)

\begin{tabular}{c|c|c}
\hline \hline & 異常感群 & 燕下困難群 \\
\hline \multirow{2}{*}{ 液体 $(\mathrm{A}$ 值) } & $235 \pm 87$ & $235 \pm 110$ \\
& $120 \sim 450$ & $67 \sim 500$ \\
\hline \multirow{2}{*}{ 液体 (B值) } & $559 \pm 99$ & $492 \pm 63$ \\
& $400 \sim 750$ & $390 \sim 610$ \\
\hline \hline \multirow{2}{*}{ 固形 (A值) } & $456 \pm 329$ & $700 \pm 662$ \\
& $200 \sim *$ & $150 \sim *$ \\
\hline \multirow{2}{*}{ 固形 $(\mathrm{B}$ 值) } & $469 \pm 138$ & $402 \pm 103$ \\
& $300 \sim 890$ & $200 \sim 650$
\end{tabular}

* : 測定困難

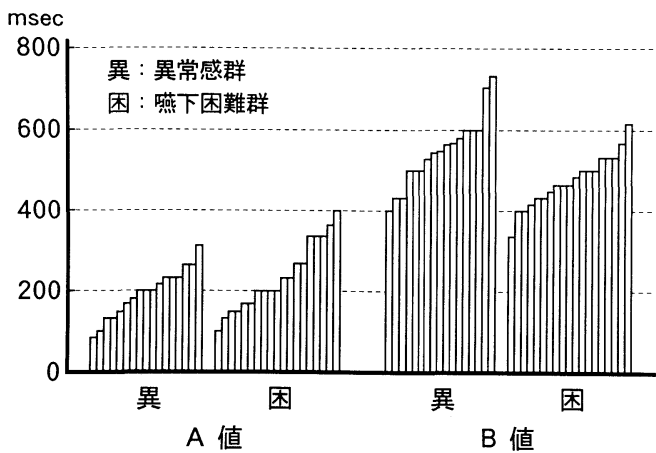

a . 液体造影剂の通過時間
く認められた．このため測定可能例での平均值 は嚥下困難群が延長していたが，統計的に差は 認められなかった. $1000 \mathrm{msec}$ を越える症例は 異常感群で 2 例, 曣下困難群で 7 例に認められ た. らち, 測定困難例の 4 例 (異常感群 1 例, 嚥下困難群 3 例) は嚥下反射が誘発されるまで 飲み込もらとする曣下運動が数回必要で，5秒 以上経過しても嚥下反射が誘発されなかったの で測定困難とした。

\section{考察}

正常の咽頭は種々の bolus に対応して鱟下す る能力を保有しているとされており3)，bolus の硬度, 成分, 温度, 量の違いによって咽頭が どのように適応して，燕下活動を行っているか は興味深いところである。

bolus の違い，とくに液体造影剂と固形造影 剂の違いを検討するため，パン，クッキー，マ シュマロ,カプセル，タブレット，ローストビー フ, チキンレバー，エッグサラダサンドウィッ チや寒天などを利用した種々の固形造影剂が用 いられている4) 14)。このらちカプセル，タブ レットは通常の固形物燕下とは異なると考兄ら れる。近藤ら ${ }^{14)}$ はバリウムを混合し固めた寒 天を報告しているが，他の固形造影剂のほとん ぞが液状バリウムに浸ける方法で，舌ざわりの 点で食べにくいといら久点があった。著者らの 作成した固形造影剂はパンの材料に造影剂を加

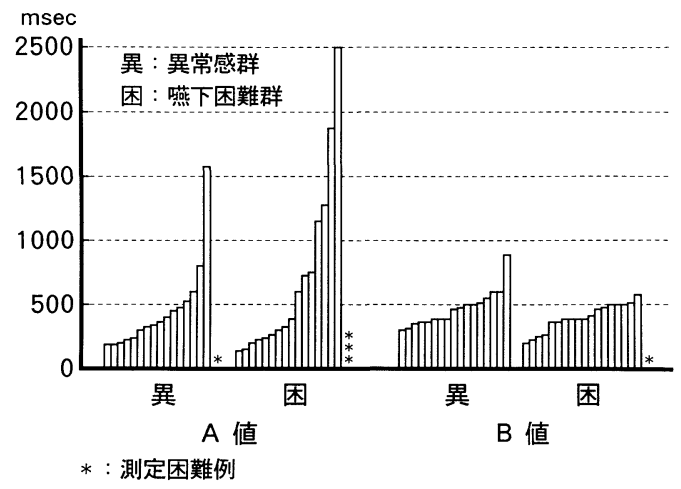

b . 固形造影剂の通過時間

図 5 各群の造影剂通過時間 
える方法で, 非常に食べやすいものとなった1). 加えて簡単に作ることができ, 冷凍保存可能で 電子レンジを用いれば30秒たらずで解凍でき, 日常臨床応用に簡便と考えている.

従来の固形造影剂による検討の多くは食道通 過に関するもので，燕下第 II 期を観察した報告 は少ない. Curtis ら ${ }^{13)}$ は直径 $13 \mathrm{~mm}$ のバリウ ムタブレットまたは直径 $10 \mathrm{~mm}$ のパンを $3 \sim 5$ $\mathrm{ml}$ のバリウムと一緒に與下させ検討した結果, 固形物を立位でスムーズに與下する因子として， (1)口腔より咽頭へ送り込む水平方向の充分な推 進力, (2)口腔上り胃までの充分な広さ, (3)重力 を含む bolus の速度, の 3 点の必要性を述べて

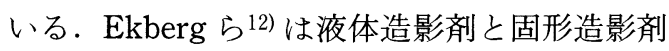
(バリウムに浸けたローストビーフ)とに拈ける 正常者の曼下動態を検討し, 喉頭蓋の運動, 喉 頭前庭の閉鎖, 輪状咽頭筋の弛緩や喉頭挙上飞 は差はなく, bolus の先端の口峡部から食道入 口部までの通過時間に差を生じたと報告してい る.すなわち, 固形造影剤の方が通過時間が長 く, これは口峡部より咽頭へbolus を送り込む のに口腔および舌の筋力が影響することに関連 があると推論している.

今回, 著者らは異常感群打よび燕下困難群に おいてバリウムパンで検討したところ，液体造 影剤に比較してA值(bolus の先端が口峡部を 越え食道入口部に達するまでの時間)の延長が 認められた。 バリウムパンが舌根に貼りつき咽 頭へ送り达みにくい所見, 咽頭の分割嚥下や喉 頭蓋谷停滞所見などが観察され，A值の延長の 要因と考兄られた．A值は bolus が口峡部に達 して鮐下反射が起こるまでの時間を含んでいる と考えられる. したがって，咽頭へ送り込みに くい所見は Ekberg ら ${ }^{12)}$ が述べている口腔およ び舌の筋力の影響を, 咽頭分割嚥下は咽頭収縮 筋の筋力低下を, 喉頭蓋谷停滞所見は咽頭知覚 の低下に基づく燕下反射の減退を反映している と推察する.

定性的所見についてはCurtis ら ${ }^{13)}$ は固形造 影剂の咽頭停滞部位として中咽頭, 喉頭蓋谷,
梨状陥凹, 輪状咽頭部を挙げている. 予備検査 での正常例では停滞所見はなかったが，今回， 與下困難群に Curtis ら ${ }^{1)}$ の所見と同様に固形 造影剂が喉頭蓋谷や下咽頭(梨状陥凹) に停滞す る所見が多く認められた。これらの症例では日 常の食餌摂取時にも咽頭停滞現象が生じ, 誤嚥 はないが飲み达みにくい感じがするといら訴兄 を引き起こしていると推察された，かかる與下 動態は液体造影剤では検出できず, 固形造影剂 の導入によりはじめて明らかにされたものと考 えられる。

また曼下困難感のない異常感群にもA 值の延 長や固形造影剂の咽頭停滞所見が認められたこ とは, 咽喉頭異常感の成因の一つに軽微な嚥下 異常が関与しているとの考皃年)を支持すると い方る.

以上のように, バリウムパンによる咽頭食道 透視を異常感群や與下困難群に導入した結果, バリウムパンでは定量的にも定性的にも液体造 影剤と異なる所見が認められた。このことより バリウムパンは嚥下に負荷を与え, bolus 推進 力の低下や臙下反射の減退の評価を行らのに有 用で, 軽微な嚥下異常を明らかにする検査手段 であると考えられた。

今回の検討では対象症例に比べ正常例の検討 数が少なく，まったく愁訴のない正常例に执い て固形造影剤の通過時間の延長, 停滞所見など の現象が生じないか，さらに検討する必要があ ると考えている。

さらに，固形造影剤は高秢者の與下機能評価 にも有用である。著者らは今回観察された bolus の喉頭蓋谷停滞所見や咽頭分割嚥下など の所見が高㱓者でしばしば検出されていること を報告している16)。 また, 脳血管障害例 ${ }^{17)}$ や舌, 口腔, 扁桃腫瘍術後 ${ }^{18)}$, 下咽頭腫瘍再建術後 ${ }^{19)}$ の鱟下機能の精查にも用いられ，種々の疾患で の鱟下動態の把握に有用と考兄られる. しかし 前述したよらに, 固形造影剂による透視は材料, 方法ともにまだ統一されて扔らず，他施設での 比較検討が困難であり今後の検討が望まれる. 


$$
\text { まとめ }
$$

著者らの試作した固形造影剂(バリウムパン) を用い, 咽喉頭異常感症例17例 (異常感群), 食 塊與获下時に異常を訴える症例19例(與下困難群) の計36例の嚥下動態を定性的および定量的に検

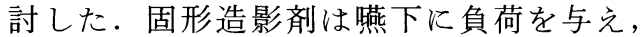
bolus 推進力, 嚥下反射の動態を反映するので, 軽徽な嚥下異常の検出に有用であると考兄られ た.

本論文の要旨は第 42 回日本気管食道科学会(鹿児島 市) および第 8 回咽喉頭異常感症研究会(福岡市)で口 演した

\section{参考文献}

1）稲木匠子, 丘村 熙, 森 敏裕: 固形造影剂の 試作とその燕下動態.耳鼻 $36: 82 \sim 85,1990$.

2）丘村 熙，稲木匠子，森 敏裕：咽頭 - 食道透 視システムの工夫 一 digital fluorography の利 用一。耳鼻臨床 $82 ： 1767 \sim 1771,1989$.

3) Buchholz DW, Boszma JB and Donner MW : Adaptation, compensation and decompensation of the pharyngeal swallowing. Gastrointest Radiol 10 : 235 239, 1985.

4) Wolf BS : Use of a half inch barium tablet to detect minimal esophageal strictures. J Mt Sinai Hosp 28 : 80 95, 1961.

5) Kelly JE : The marshmallow as an aid to radiologic examination of the esophagus. $\mathrm{N}$ Engl J Med 265 : 1306 1307, 1961.

6) Bosch AR, Dietrich R, Lanaro A, et al : Modified scintigraphic technique for the dynamic study of esophagus. Int J Nucl Med Biol 4 : 195 199, 1977.

7) Fisher RS, Malmud LS, Applegate G, et al : Effect of bolus composition on esophageal transit ; concise communication. J Nucl Med 23 : 878 882, 1982.

8) McCallum RW : Radionuclide scanning in esophageal disease. J Clin Gastroenterol 4 : 67 70, 1982.

9) Logemann JR : Evaluation of swallowing disorders. Evaluation and Treatment of Swallowing Disorders. pp 97 98, CollegeHill Press, California, 1983.

10) Miller RM : Evaluation of swallowing disorders. Dysphagia : Diagnosis and Management (ed by Groher ME). pp 99 102, Butterworth Publishers, Massashusetts, 1984.

11) Jones B, Kramer SS and Donner MW : Dynamic imaging of the pharynx. Gastrointest Radiol $10: 213 \sim 224,1985$.

12) Ekberg O, Liedberg O and Owall B : Barium and meat. Acta Radiol [Diagn] $27: 701 \sim 704$, 1986.

13) Curtis DJ, Cruess DF and Willgress ED : Normal solid bolus swallowing erect position. Dysphagia 1: 63 67, 1986 .

14）近藤玲子, 川端五十鈴, 堀口利之, 他: 固形造 影剤による嚥下機能の評価. 日気食会報 40 ： 284 287, 1989.

15）稲木匠子：咽喉頭異常感症に拈ける潜在的嚥下 異常の研究 一下咽頭・頸部食道過緊張症の提 唱一. 日耳鼻 $94: 1234 \sim 1243,1991$.

16）丘村 熙, 稲木匠子, 森 敏裕, 他: 高㱓者の 嚥下機能 一咽頭食道透視よりの観察一. 日気 食会報 $42 ： 116 \sim 120,1991$.

17) Logemann JA : Swallowing disorders after treatment for oral and oropharyngeal cancer. Evaluation and Treatment of Swallowing Disorders. pp 178 180, College-Hill Press, California, 1983.

18) Robinns J and Levine RL : Swallowing after unilateral stroke of the cerebral cortex; preliminary experience. Dysphagia $3: 11 \sim 17$, 1988.

19）福井康二, 丘村 熙, 森 敏裕, 他: 大胸筋皮 弁による下咽頭再建術後の燕下機能. 頭頸部腫 瘍 $17: 127 \sim 131,1991$.

$\left(\begin{array}{l}\text { 原稿受付 : 平成 } 4 \text { 年 } 8 \text { 月 } 11 \text { 日 } \\ \text { 原稿採択 : 平成 } 4 \text { 年 } 9 \text { 月 } 14 \text { 日 } \\ \text { 別刷請求先 : 稲木匠子 } \\ \text { 斥 } 790 \text { 松山市交町 } 1 \\ \text { 松山赤十字病院耳鼻咽喉科 }\end{array}\right)$

